\title{
Knowledge art
}

\author{
Artwork and invention \\ Bruno Caldas Vianna \\ Academy of Fine Arts \\ Uniarts Helsinki \\ Helsinki, Finland \\ bruno.caldas@uniarts.fi
}

\begin{abstract}
This paper depicts a dialogue between art and technology, by examining coincidences and differences between artworks and inventions, their conditions and stakes. By examining these categories through the same lenses, this approach hopes to build bridges between the two, or even propose that they stop being seen as separate institutions.
\end{abstract}

The text starts by looking at how the separation between art and science occurred in terms of etymology. It then builds upon the idea of skill, which is not far from art's original meaning. We look at how different they might be for science and art, in terms of intellectual and bodily skills.

Since both fields have high stakes in originality and uniqueness, the paper looks into the issues of each one and the systems put in place by society to assure rights for artists and inventors.

A turn towards knowledge as a raw material for art has been happening for at least a century, and was accelerated in the last decades by practices which incorporated several aspects of science and technology into the creative arts. To account for these practices, the categories of discrete art and invention art are proposed, and existing ones such as conceptual art are explored.

The paper does not draw hard conclusions. It instead proposes a few leads to understand new stances within art and technology, and leaves the definition of knowledge art as an open concept.

\section{KEYWORDS}

Art and technology, patents, invention, copyright, science, art, conceptual art, artistic research, intellectual rights

\section{Introduction}

This paper intends to gather starting points for a comparison between artworks and inventions, and consequently for art and technology themselves. I will look into how they became separate fields; analyse some institutions in society that account for this separation; and finally speculate whether they start merging again, based on a substantial turn in the art world towards a knowledge-based common practice.

In most of human history, art and science were not separated. In fact, the concept of art as we understand today is relatively recent. The word art comes from the latin Ars, which means skill in "in producing any material form" or in "joining something, combining, working it.[17] This meaning persists in derived words used today such as artifact, artificial, or in the title Bachelor of Arts, meaning "human workmanship." The German language term for art, Kunst, doesn't descend from Latin; yet the use to notate human-made remains, for instance, in Kunstschnee, "artificial snow". In road building terminology special structures such as overpasses and bridges are designated "special artworks."[27] This places art in opposition from nature, ie, art would be everything made by women and men, including poems and statues, but also houses, boats, knives and clothes. When Seneca claims that all art is but an imitation of nature, he refers not only to the current expressive understanding of it, but also to the skills developed to imitate the architecture of birds' dwellings or the sharpness of the claws of bears.

So when did the concept of art change? When did the West begin to define what we call art today - paintings, literature, 
music - from other creations such as the steam engine? And even more importantly, where and how is the border between the categories traced?

This text mentions the West explicitly because this concept was developed in Europe, and that creates challenges in identifying these issues in non-Western societies. James Elkins dealt with the challenge of fitting non-artistic images within the context of the art world.[11] The West/non-West cultural distinction is not used remorselessly here, in the light of its recent applications to interfere with the lives of immigrants.[2] There are better ways of dealing with the differences between European culture and its counterparts. I'll use the term nonetheless, not only because it is the standard in art history, but also since the article intends to propose a criticism of how such discipline is built.

Even in Western countries that don't use a Germanic or Latin language, the naming of art reveals troubles in baptizing the self-expression activities of humans. Greeks

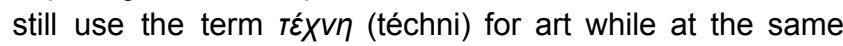
time using rexvoloyía (technología) for technology. Technical and artistic skills remain in one category, since réXV $\eta$ also designates craftsmanship in general. On the other end of Europe, the Finnish standard is to use the word taide, which was coined only in the 1840's by wordsmith Wolmar Schildt[21], and is derived from the verb taitaa, which also means to master, to be proficient at something, or to have a skill.

If in the nineteenth century there were still western languages without a normalized term for art, it makes us wonder how recently this naming process took place. While it is not the role of this paper to propose an answer to a question that was raised by some many prominent historians, it can provide some clues. The Oxford English Dictionary claims that "Although this is the most usual modern sense of art when used without any qualification, it has not been found in English dictionaries until the 19th century."[31] The same source does not list texts using this meaning before 1668 .

Hans Belting's investigation on "the history of image before the era of art"[3] identifies a new role for images as art connected to the questioning of religious icons made by the Reformation in the sixteenth century. In fact, the most recent work studied in this seminal book is Raphael's Sistine Madonna, painted around 1513. One of the first books on art history is the compendium published in 1568 by Georgio Vasari, Lives of the Most Excellent Painters, Sculptors, and Architects. As its title already suggests, the word artist is never used in it. The subjects are referenced by their specific crafts. In Le Vite[26] the word art is used, but again it is applied much more in the sense of skill.
In any case, even if art was born thousands of years BC probably together with mankind - it was not baptized earlier than a couple of centuries ago. And before this baptism, we used to think of any human activity that required skills as art. The reasons for these categorizations are beyond the scope of this text, so it will rather look into its consequences, and what they mean in a context where art and technology seem destined to merge again. But first, since the word art does not apply anymore to every type of craft, let's do the exercise of looking at skills as if the schism between art and technology never existed.

In order to differentiate it from the current understanding of arts, whenever the paper uses the term art in its original, broader meaning, it will be noted in italics - art.

\section{Skill}

In times when automation takes over all aspects of production and even creativity, it is hard to make an argument for artisanal skill. The craft of a shoemaker had to be much more appreciated in the middle ages than it can ever be now, even if there are brands which might claim to produce handmade shoes. That is not to say that mechanical skills are now completely scorned. Good drivers will always be in high praise; the productivity of a sweatshop worker is directly related to her or his ability to perform fast and without mistakes.

I'll resist the temptation to classify a skill as creative or not creative. All tasks can benefit from innovative approaches, even if repetitive and imposed. It is true that a given skill can be learned to the point of perfection, without any added improvements or personal touches. But someone, at some point, invented this set of movements or this process. So we can say that every skill is a product of human art.

There is another distinction that might be very tempting to make, yet not less risky: the non-binary spectrum between bodily and intellectual skill, a distinction analog to the one between blue collar and white collar workers. Within artistic practice there are plenty of examples where mastering the body is a requirement. Dancing, singing, playing musical instruments or acting require extensive training or at least a coherent approach. And even in arts, a case can be made for performers that thrive for perfection instead of innovation. An opera singer can deliver a flawless, classic interpretation of a lied; she or he might then be praised for integrity, and at the same time be criticized for not incorporating personal expression. Of course, such perfection is obtained through comparison to previous installments of the same work, which will bear the mark of 
originality. That doesn't necessarily take away its artistic merits.

The skills required to compose the opera, however, demand less from the body and could be performed without any biomechanical capabilities. Also writers can use an assortment of supports to create a text - pen, typewriter, tape recorders; but a choreographer will almost always be relying on bodies. A recent term, knowledge worker, has been coined to describe jobs that rely heavily on thinking and solving problems, with some discussion whether this implies creative work or not.[19]

At this point we can note a specificity inherent to non-bodily tasks, which is the inevitable creation of a documentable process that can be replicated. A mental skill is always expected to generate a trail. If you won't write down your idea, it might get lost forever. In comparison, a dance movement might exist only in the moment of the performance, if it is not documented in a set of instructions or a video recording. Although this seems like a superficial effect, it will be important later for the argument of this paper.

Still, the distinction is never easy to make. No mind exists outside a body; likewise dance movements are not a product of the body alone. Painting and sculpting require fine dexterity, but it also requires the previous imagination of what is to be sculpted or drawn. One can make the argument that once the blueprint is finished - picture or statue - it can, at least in our times, be reproduced by a machine and dispense with the body. What about photography, for instance? An action photographer needs the bodily ability to press the trigger at the most significant moment. But studio photographers might take their time in materializing an imagined scene, for which their body might nor ever be required - even the shutter might be pressed by an assistant. And the speed and resolution of current cameras allow an image maker to capture time continuously, leaving the task of choosing the best moment for a later time, when the mind can work without immediate physical demands.

Outside the spectacle, sports and entertainment realms (in which I begrudgingly include all types of fine arts, polemics apart), body skills lose protagonism, and the ability required to invent techniques, concepts, programs take their place.

It is hard to deny the relevance of the skills necessary for innovation in our society. Here I'm speaking more in the old terms of art skills, that is, including technology, medicine, social science, and also expressive activities under the current umbrella term of art. In other words, the skills needed for invention. The problem is that, when we decided to remove self-expressive endeavors from the more general technical skills and create the current category of art, new criteria were invented to evaluate such production. I will now describe the ideas of originality and uniqueness, and how they are represented in the legal framework built around the business of creation.

\section{Originality and uniqueness}

Being original and/or unique represent some of the highest stakes in science and technological development as well as in the expressive arts, and that's why they must be addressed here in tandem. These two qualities are complementary and different. What is convenient for this discussion is that in the case of objects, the concept of original and unique can be used interchangeably. It is the case where originality can also mean authenticity, genuineness. The uniqueness can be indicated by the impossibility to create a copy of it. The Eiffel Tower is unique not only because it was the historical construction built for the Paris World Exhibition, but also because its location makes it unique. Another identical tower can be built, but it won't be "the" Eiffel tower. Objects that were destroyed but rebuilt in the same place suffer the same fate, as it is the case, for instance, for historical edifications bombed in wars. This definition is never so straightforward since any physical thing will suffer some sort of decay: buildings made of wood must be permanently reconstructed. A 17th century wooden church might not have one single plank from the time of construction and still be considered original. A problem that museologists must face constantly is the challenge of defining how much an item can be maintained before losing its genuineness, but one can always argue that the continuum provided by the slow replacements already provide the connection to the first historical installment of the object.

More obvious is the fact that manually created artworks cannot be copied because simply they are very difficult to replicate. It is exactly the skill - the art - what makes them unique: only the most talented forgers will be able to not convey their own specific dexterity to the imitations. And in that case, they will fall into the already mentioned skill of perfect replication. As Walter Benjamin notably described[4], the advent of mechanical ways of creating copies complicated the notion of uniqueness. The original artwork has an aura, no matter how restored it has been. But a photo print, of which millions of copies can be made? Even if we know that at an atomic level no two objects are identical, two well executed prints of a picture will look exactly the same. Although understandably much more attention is given in the case of artworks, trouble started much before, when industrialization replaced the work or 
the artisan; a scissor would no longer be appreciated for the ironsmith that cast it, but for the company producing it.

When dealing with ideas, instead of things, originality takes a different turn, and proving uniqueness is not so simple. The understanding of a concept is much more prone to subjectivity. Here, I'm not using the word concept in the philosophical, Kantian sense of an a priori category. What I call a concept is a new arrangement of things or other concepts, that is used to explain a phenomenon, or to propose a new method that might be used to create things. Within this definition, a concept could refer to an invention, an artistic style, or choreography.

Hence the difficulty in determining originality and uniqueness in concepts. In human culture, nothing is created out of thin air. All production is the result of some recombination of previous developments, both in art and science. An original work is able to stand out from its peers by proposing a combination that didn't exist before. In systems theory (and other theoretical frameworks) the appearance of a new feature, able to perform new tasks, but based on existing features of the system, is named emergence. This very concept is built on something formulated by Aristotle ages ago: "In the case of all things which have several parts and in which the totality is not, as it were, a mere heap, but the whole is something beside the parts"[1]. And since the conditions for the emergence of new concepts are shared across many peers, it is not uncommon to see similar concepts appearing at the same time. That means that although original (authentic and genuine), they might be non-unique (even though, of course, concepts also are never exactly the same).

This phenomenon is not uncommon in science, and might be called multiple discovery or simultaneous invention. Newton and Leibniz both discovered calculus working independently from each other, only ten years apart[16]. While working on the theory of evolution, Darwin received a letter from his pupil Alfred Russel Wallace in which he described the same conclusions on natural selection[9]. The list of simultaneous inventions is long, including the electric telegraph, the airplane, the jet engine. The RSA algorithm[22], used widely in cryptography methods, had already been proposed in a classified document, five years earlier.[8]

More importantly, what are the stakes for uniqueness in a concept? For the advance of knowledge and culture - or mankind in general - it doesn't matter how many people discovered the same thing. In fact, in many cases a given advent is only widely adopted after findings subsequent to the first one. But in the history of concurrent development, tales of fierce fighting abound. There is a high incentive for being the first, and the reward is backed by a complex system of use restrictions, as we will see shortly.

Questions of uniqueness didn't appear often in the arts due to the fact that, as we have seen, crafted art objects usually bear the quality of singleness. And in terms of commercial value, the issue of duplicates was never a problem for galleries - limited editions and artist-issued certificates of authenticity serve as substitutes for the object's aura. Recently, non-fungible tokens (NFTs) also emerged as an option to create artificial scarcity for artworks. But when artists start relying on discrete systems for their trade - from image generating software, to $3 \mathrm{~d}$ printers or even plain algorithms such as performance scores or Sol Lewitt's instructions - the odds are that similar concepts will appear at some point. And if there is a specific category of conceptual art, we can imagine that concurrent concepts might end up clashing.

\section{Patents, copyrights and other invented protections}

The most institutionalized methods for validating uniqueness and originality in our society - again, in science as well as in the arts - are the intellectual rights systems. The creation of enclosures to protect originality and uniqueness is a process parallel to the enclosure of common lands in the eighteenth century[18]. Patent-like incentives were already issued in Greece, around 500 B.C., and also in the Republic of Venice in the mid-1400s, but the first modern law to create a similar sort of protection is considered to be the British Statute of Monopolies, from 1624. Copyright protection was established in France in 1498 and in the next century in the United Kingdom, although they worked more like monopolies on printing. The Statute of Anne, from 1709, limited the periods of such monopolies, fostering competition; but the rights of authors weren't recognized in England until 1774[9]. Other platforms of protection also exist, such as trademark systems and trade secrets; in 1998 the European Union created regulation on design protection[32]. These are usually addressed under the broader term "Intellectual Property", but the idea of property applied to ideas and content has been criticized, as property implies some kind of scarcity, and that does not apply to intellectual works[28], the same way one cannot claim rights to sunlight or air.

How are patents and copyrights related to uniqueness and originality of concepts and physical artworks? In very broad terms, patents cover ideas and copyrights cover their expressions. Not any idea can be patented: they must be "implementable" ideas. Pure concepts are therefore excluded from any kind of protection. A natural law, a 
mathematical function or a physical phenomenon also cannot be patented. A process that does something can be patented: in fact patents are commonly categorized into either products or processes.

United States law defines three criteria for the concession of patents: novelty, utility and non-obviousness. Novelty not only addresses the aforementioned originality. Existing "prior art" would be an impediment - and here the term appears again designating anything human-made, not necessarily "artistic". That includes the exhibition of the invention to be patented: once it becomes public, the creator should register it within the year, or it will become unpatentable.

Another feature of this condition is that it tries to resolve multiple discoveries: even if two people independently develop the same thing, the rights will go to the first to obtain the patent. This should in theory democratize innovation, since a patent, in theory, should be cheap to obtain; in practice, the history of simultaneous invention is full of tales of creators that, sometimes even with the granted rights, couldn't make a profit from the creation because they lacked the funds or connections to make it commercially feasible. Italian inventor Antonio Meucci registered a telephone system five years before Graham Bell, but lost expensive legal action against the latter and could never develop his product. Radio transmission was achieved by the priest Roberto Landell de Moura two years before Marconi, but the fact that he was based in Brazil limited his access to financing, even after a successful European tour demonstrating his devices[12]. In the year before the gramophone blueprint was deposited, French inventor Charles Cros submitted his own audio recording system to the French Academy of Sciences. But it was Thomas Edison's research laboratory in Menlo Park, New Jersey, that had the means to profit from it[14].

Copyright law doesn't intend to avoid simultaneity: if two artists prove that they developed the work independently, copyright could be awarded to both. Given the nature of crafted works like paintings or novels, it is very unlikely that two independent works will have the same fixed notation. But one example could be an exact same melody composed by musicians without each having ever heard the other. The opposite case is a lot more common: a composer will face the accusation of plagiarism when it can be shown that she or he heard the duplicated tune at some point before her or his own composition. That was the case for instance, of Rod Stewart's hit Do Ya Think I'm Sexy?, unconsciously inspired by Jorge Ben's Taj Mahal during a trip[24].
Utility and non-obviousness seem even harder to define, and we can see loads of patented products which are apparently useless and processes that seem too obvious, like the famous one-click shopping method granted to Amazon. In fact, the non-obviousness criteria also states that combining two well-known methods into a third new one is a case of obviousness. With millions of products and patents in existence, it becomes harder every time to come up with something that is not obvious to a skilled person. That is also one of the causes for major headaches for experts: the software patent.

Computer programs stand somewhere in between a concept, a process and a product. It is a set of instructions to execute a task. In that sense, it is a concept, even if it is used to perform something. But any software that is executed in a Turing machine (ie, any computer) is a representation of a mathematical function, and therefore would be excluded from patenting[33].

The European Union parliament rejected in 2005 a proposal to allow software patents[34]. Several decisions of the US Supreme Court also supported this stance. Still, more than 30000 software patents were granted in the EU only before 2005 and continue to be issued under different approaches[9]. In any case, the representation of software programs - the lines of code - can be copyrighted, although this copyright can be circumvented (making it kind of pointless) by writing a different code that does the same thing.

Copyrights are clearly closer to art production, with creators usually in the protected side, but also sometimes in the infringement side - like Andy Warhol and Jeff Koons, both sued by the copyright holders of photos used in their works. These cases demonstrate the difficulty in applying copyright to culture in general. After all, nothing is created out of thin air: culture is a web of citations, inspiration, references.

To address the issue, alternative copyright licenses have been proposed, with the most popular being Creative Commons. This model allows publishing with less restrictive permissions such as non-commercial use, or modification. In software, free licenses abound, such as the MIT, GPT or Apache. On top of the licensing freedom, stands also the open source movement, which avogates the publishing of the code even without reuse rights, for the sake of knowledge sharing and innovation.

To collect proceedings from copyright protection, copyright societies were created. They charge companies which use copyrighted materials, such as radio stations, movie theaters and book editors and distribute the funds among the authors. They may also prosecute people who copy 
such materials. The digitalization of supports created challenges for these institutions; in Spain, for instance, a tax on blank digital media such as CDs or hard drives destined to the copyright agency was created. The societies are often accused of preventing the fair use of copyrighted material in non-profit settings. New models of distribution such as streaming media - Spotify, Netflix, etc - are questioning the role of these agencies. It is also worth noting that, in spite of producing copyrightable material, most fine art forms, like photographs, do not profit from the services of these agencies unless the artwork ends up in a book or a movie.

In creative activities, patents play a lesser role. It is not uncommon for artists to patent musical instruments, like Prince's Keytar[20] or tools, like James Cameron's underwater dolly[7]. Filing a patent for an art piece is more challenging: how can the utility of art be proved? At the same, more and more artists have a practice within a technological framework, to the point that much of their production can be considered an invention. With that in mind, let's invent some categories of art and see how they can be seen from a viewpoint of art and intellectual legal rights.

\section{Conceptual art, discrete art, invention art and more}

Besides the well established notion of conceptual art, I also propose two other categorizations - discrete art and invention art - that will contribute to the debate on art, technology, and their relations to science and intellectual production. These three disciplines are presented here not as excludent categories, but rather as framings within the broader contemporary art production. We can think of these as labels for tagging works, artists or even movements, considering that these criteria overlap each other and further possibilities of classification. In common, they are creative endeavours that do not rely on fine dexterity skills like dancing, drawing, sports - but on intellectual skills. They represent the claim within the arts to embrace thought as a tool, like the brush or chisel. They are framed this way here for their challenge to the so-called intellectual rights: their mere existence might prove how arbitrary and unnatural the laws governing the protection of the creative craft can be.

Conceptual art has defied definitions for decades. The term rose to prominence in the sixties, but has been expanded to include previous works like Duchamp's Urinal, exactly due to the fact that they are more based on thought than mechanical skill. "With the unassisted Ready-made, art changed its focus from the form of the language to what was being said. Which means that it changed the nature of art from a question of morphology to a question of function[15]." This paper won't propose a new definition or adopt an existing one. For the purpose of the argument here, conceptual art is the art that doesn't not output a copyrightable expression, but relies exclusively on language (and thought) to exist. I understand that this would exclude some notable conceptual artworks such as Manzoni's Artist's Shit, but the point being made here (and elsewhere[23]) is that by suppressing the material expression, this category subverts the productive logic of intellectual rights protection and tries to place itself outside of a capitalist logic. By that I do not mean that conceptual art never gets sold. The lack of materiality never refrained collectors from buying this type of art[35]. It just eschews capitalism's protection mechanisms for art's own methods, anterior to the intellectual enclosures of the industrial era.

This distinction is also useful because in some cases the artworks will have outputs, but they won't be eligible for copyright. GFP Bunny is a transgenic work by Eduardo Kac, in which an albino rabbit, Alba, "was created with EGFP, an enhanced version (i.e., a synthetic mutation) of the original wild-type green fluorescent gene found in the jellyfish Aequorea Victoria."1 This made the bunny glow under certains conditions of lighting. Although the pet can be seen as a materialization of the artwork, it is not possible to copyright a living being.

The patent of a living being, however, is possible. Plants have been eligible for registration in the US since 1930 and a Supreme Court decision from 1980 granted a patent of a mouse[25]. Even though the discovery of naturally occurring genes cannot be protected, since they are a product of nature, artificially manipulated genes can[9]. Kac has made it clear that his artwork is not the bunny, but its creation, the public discussion generated by it and its social integration; and in any case, the genetic alteration process was not invented by the artist but by a company. We will not delve into the ethics question for the work, as that would be impossible to cover here. However, there could be a patentable claim to the fluorescent rabbit "product". In fact, there are several patents of fluorescent fish assigned to the GloFish company, which commercializes them ${ }^{2}$. Therefore this work also fits into the invention art category, which will be addressed soon.

I propose the discrete art classification as an analogy to discrete mathematics, which deals with distinct, separate values, states and steps. This field is defined in opposition to continuous mathematics, so it can also be seen as dealing with digital data instead of analogic information.

\footnotetext{
1 GFP BUNNY. Retrieved May 1, 2021 from http://www.ekac.org/gfpbunny.html

2 GloFish®. Retrieved May 1, 2021 from https://www.glofish.com/
} 
Discrete art would deal essentially with algorithms that describe every step of the operation, creating different states to arrive at a final outcome - or artwork, possibly. Software-based generative arts are closely associated with discrete systems, but similar processes can also be found, for instance, in the scores of performances. One can also see interactive works (installations, narratives) as state machines, where the users trigger different possible configurations.

Discrete art overlaps in many features with conceptual art. I would consider Sol Lewitt's instructions for works as a perfect example of discrete art, and yet he is considered a conceptual artist[30]. Casey Reas' software-generated tableaus are also examples. In fact, he co-created one of the main tools for discrete artists, the Processing programming platform. In another paper [6] I discuss the change of paradigm caused by artificial intelligence within generative arts, as they are no longer restrained by specific styles, but can be used as a generic tool that can be trained in any style.

Very often, discrete art produces copyrightable work. Besides, as mentioned before, code itself is a form of expression eligible for protection; so that would also be the case, for instance, for Yoko Ono or Sol Lewitt's sets of instructions. Nevertheless the financial gains for such artists rely much more on the gallery system than copyright societies. And again, the recent advent of non-fungible token platforms also provided a revenue system for creators that circumvents the traditional copyright system.

One interesting effect of discrete art is the potential to replicate the aforementioned bodily skills, by transforming continuous movement into discrete instructions. We live in times where the functions of the body are being executed (and outperformed) by machines. This shift is not exclusive to science and engineering, but also within the arts themselves, as we can have sculptor robots and artificial intelligence music performances, and even a desktop printer can be seen as a replacement for the bodily skills of illustrators.

The criteria I propose to define invention art is more banal: it is art that could be patented as an invention, if the patent system could reconfigure its usefulness criteria. Right now, this utility requirement seems arbitrary enough: we can find approved applications for bird diapers or a method to create artworks based on dog nose smudges. As for the other criteria, novelty would stand as long as the artist would be the first to publish and register her/his art. Quite often the artist claims an artistic application to an already existing invention, which would not fit my proposal. As for non-obviousness, that is where artists are likely to excel in comparison to other inventors.

The invention of a fluorescent bunny was already mentioned, but the list of potential artist inventions is long. Ana Laura Cantera ${ }^{3}$, an Argentinian electronic artist, deals constantly with the combination of organic and electric methods. In a residency at the Nuvem Art and Technology space, she proposed, for instance, the creation of self powered bioconstruction bricks ${ }^{4}$. Jonathan $\mathrm{Kemp}^{5}$ and Martin Howse ${ }^{6}$ developed (among many other devices) the telluro-geo-psycho-modulator, that allows to investigate the thesis that "brain states are modulated by the interference of weak geomagnetic fields, and that such modulations cause anomalous experiences."

Artist Gilberto Esparza invented a contraption that allows plants to move and search for water ${ }^{8}$, among many others. Daniel Rozin is well known for his series of innovative mechanical mirrors ${ }^{9}$, many of which have been sold as art pieces. As far as I could ascertain, there are no patents for those, but he does hold valid patents for original visual methods and a 3D scanner. Julius von Bismarck actually holds a patent to one of his artworks, the Image Fulgurator, ${ }^{10}$ although he claims that the invention was freely copied and widely used. In fact, Julius also has a piece which is based on public patent drawings, named Perpetual Storytelling Apparatus.

The interesting thing about this unwillingness to register creations is that it allows for simultaneous inventing. A patent on an art piece, in theory, creates an impediment for other similar work. In 2009, Brazilian artist Pedro Veneroso developed the concept for an interactive installation named Paradoxo: Chuva (Paradox: Rain) ${ }^{11}$. It consisted of a room equipped with a grid of water outlets in the ceiling,

\footnotetext{
3 Ana Laura Cantera. Ana Laura Cantera. Retrieved May 2, 2021 from https://analauracantera.wordpress.com/[1]

4 Ana Laura Cantera - nuvem. Retrieved May 2, 2021 from http://nuvem.tk/wiki/index.php/Ana_Laura_Cantera

5 xxn [jonathan kemp]. Retrieved May 2, 2021 from http://xxn.org.uk/doku.php

6 micro research/xxxxx - Martin Howse. Retrieved May 2, 2021 from http://www.1010.co.uk/org/

7 Telluro-geo-psycho-modulator [psychogeophysics]. Retrieved May 2, 2021 from

http://www.psychogeophysics.org/wiki/doku.php?id=telluro-geo-psycho-modu lator

8 Plantas Nómadas / Nomadic Plants - Gilberto Esparza -. Retrieved May 2, 2021 from http://gilbertoesparza.net/portfolio/plantas-nomadas/

9 Daniel Rozin Interactive Art. Retrieved May 2, 2021 from http://www.smoothware.com/danny/

10 Image Fulgurator: juliusvonbismarck.com. Retrieved May 2, 2021 from https://juliusvonbismarck.com/bank/index.php/projects/image-fulgurator/2/

11 Pedro Veneroso | Portfolio. Retrieved May 2, 2021 from http://pedroveneroso.com/project?id=17
} 
controlled by electronic valves and presence sensors. The system would open and close the faucets in a way that water would be falling throughout the whole room, except on and around the visitors. The artist submitted the project for financing, but was never able to fund it beyond the blueprint. Just a couple of years later, a project named Rain Room $^{12}$ was developed by the artist duo Random International, with the exact same mechanism. It took the art world by storm, being presented in the Barbican in London, MoMA in New York, and several other venues around the world.

There is no evidence that the duo was inspired by the Brazilian project. It is probable that they were influenced by the Water Swing Project ${ }^{13}$, released in 2011. Veneroso's concept, however, was conceived before that. But this anecdote is an example of the difference between works based on concept and works based on artistic skill. Two renaissance painters depicting the birth of Jesus would certainly end up with very unique works. If executed, Veneroso's installation would certainly be physically different from the one seen at MoMA. But in such projects, the concept has a much greater weight than the execution and therefore they could be seen as replicas. The story also reinforces the notion that, like the cases of great inventions described above, the one who reaps the rewards is not necessarily the first to come up with the concept, but those who have the funding to execute it.

Beyond the scope of this article are also two concepts that could fit into the idea of knowledge art. Hacker Art[13] is a category that is being developed by other authors, which could have many intersections with the classifications above. And finally, Artistic Research[5] has become a vast field, with many competing and valid definitions. It might be treated as art based on investigations, or as an academic method flexible enough to validate artistic practice as institutional, or even as an appropriation of scientific research criteria by artists - in all cases, it will fit into a knowledge-based creative expression.

\section{Conclusions}

This paper is focused rather on gathering evidence to forge a landscape of possible entanglements between art, science and their features than to arrive at a precipitated conclusive definition. But it can list a few thesis based on the clues highlighted.

\footnotetext{
12 RANDOM INTERNATIONAL. Retrieved May 2, 2021 from https://www.random-international.com/rain-room-2012

13 Waterfall Swing. Waterfall Swing. Retrieved May 3, 2021 from https://www.waterfallswing.com
}

It seems like the reframing of the term art was made to separate science and technology from subjective/expressive craft, about the time when the age of enlightenment needed to validate reductionist ideas based on reason and the scientific method. An analog distinction also started to be made between the psychomotor artistic skills of fine art and the intellectual and engineering skills of invention. With the prevalence of the capitalist system, a framework to protect inventions and artworks was put in existence, which valued originality and uniqueness in detriment of collaboration and remixing.

One thing that can be generalized about most inventors and artists is that they haven't been benefitting from patents, exactly as their counterparts of yore - in the time of art before art. In the end, corporations and lawyers seem to be the ones who benefited the most from the patent system. The cases of successful independent inventors and wealthy artists are exceptions and not the rule. The main argument towards the system is the incentive to innovate; nevertheless, the argument is invalidated when we see that unprotected scientific fields such as pure mathematics and particle physics also innovate continuously. Scientists have always been motivated by the thrill of innovation itself, independent of financial awards. Most of the innovation seen in cyberspace today - social networks, streaming media - flourished in areas which are not much prone to patenting. And artists, as usual, continue to innovate as always, without the need to resort to invention protection.

It can also be said that some of the most original movements in culture happened in defiance of copyright. Hip-hop was built heavily on the culture of sampling, and had to pay the financial consequences of this audacity[29]. Like inventors, most musicians and book writers earn neglectable income from copyright societies; the only ones who really benefit are a few top sellers and music stars.

As the arts started to reclaim language and concepts as raw materials, they also reappropriated intellectual methods as an integral part of the field, closing again the gap between sciences and what is now known as the arts. This tendency is accentuated by more recent appropriations described as discrete art, invention art, hacker art and possibly even Artistic Research.

The paper purposely opts not to define knowledge art, its title concept. It rather offered some elements and hints of what this could be, leaving it open for others to build upon and remix the concept - as it is the practice within all open knowledge and culture, and was the general rule before science and technology were stripped away from the arts. 


\section{REFERENCES}

[1] Aristotle. 1933. Metaphysics. Harvard University Press Cambridge, MA.

[2] Guest Authors. 2020. The Epistemic Production of "Non-Western Immigrants" in Denmark. The Disorder Of Things. Retrieved April 25, 2021 from

https://thedisorderofthings.com/2020/09/30/the-epistem ic-production-of-non-western-immigrants-in-denmark/

[3] Hans Belting. 1994. Likeness and Presence: A History of the Image Before the Era of Art. University of Chicago Press.

[4] Walter Benjamin, Michael William Jennings, Brigid Doherty, Thomas Y. Levin, and E. F. N. Jephcott. 2008. The work of art in the age of its technological reproducibility, and other writings on media. Belknap Press of Harvard University Press, Cambridge, Mass.

[5] Henk Borgdorff. 2012. The conflict of the faculties. Perspectives on artistic research and academia. Leiden University Press.

[6] Caldas Vianna, Bruno. 2020. Generative Art: Between the Nodes of Neuron Networks. Artn. 26 (July 2020). DOI:https://doi.org/10.7238/a.v0i26.3350

[7] Michael H. Cameron and James F. Cameron. 1991. Apparatus for propelling a user in an underwater environment. Retrieved April 30, 2021 from https://patents.google.com/patent/US4996938/en?oq=j ames+cameron

[8] Clifford C. Cocks. 1973. A note on non-secret encryption. CESG Memo (1973).

[9] Charles Darwin, Alfred Russel Wallace, Sir Charles Lyell, and Joseph Dalton Hooker. 1858. On the tendency of species to form varieties: and on the perpetuation of varieties and species by natural means of selection. Linnean Society of London.

[10] David Kline and David Kappos. Introduction to Intellectual Property. OpenStax, Houston, Texas. Retrieved April 30, 2021 from https://openstax.org/books/introduction-intellectual-pro perty/pages/1-introduction

[11] James Elkins. 1995. Art history and images that are not art. Art Bull. 77, 4 (1995), 553-571.

[12] Leonardo Foletto, Autonomia Literária, and Cauê Ameni. 2020. A Cultura é Livre Uma História Da Resistência Antipropriedade. Autonomia Literária, São Paulo. Retrieved May 3, 2021 from

http://public.eblib.com/choice/PublicFullRecord.aspx?p $=6519082$

[13] Daniel de Souza Neves Hora. 2015. Teoria da arte hacker: estética, diferença e transgressão tecnológica. (2015).

[14] Friedrich A. Kittler. 1999. Gramophone, film, typewriter. Stanford University Press, Stanford, Calif.

[15] Joseph Kosuth. 1966. Art After Philosophy (1969). Art Philos. Collect. Writ. 1966-1990 (1966).

[16] Alexandre Koyre and I. Bernard Cohen. 1961. The Case of the Missing Tanquam: Leibniz, Newton \& Clarke. Isis 52, 4 (December 1961), 555-566. DOI:https://doi.org/10.1086/349500
[17] Charlton T. Lewis and Charles Short. 1966. A Latin dictionary: founded on Andrew's ed. of Freund's Latin dictionary. (1966).

[18] Karl Marx. 2018. Capital volume 1. Lulu. com.

[19] C. McKercher and V. Mosco. 2008. Knowledge Workers in the Information Society. Lexington Books. Retrieved from https://books.google.es/books?id=_MeCr31C9S8C

[20] Prince R. Nelson. 1994. Portable, electronic keyboard musical instrument. Retrieved April 30, 2021 from https://patents.google.com/patent/USD349127/en

[21] R. E. Nirvi. 1947. Lauri Hakulinen, Suomen kielen rakenne ja kehitys (Structure and Development of the Finnish Language), 2 vols. Helsinki: Otava, 1941-46. Am. Slav. East Eur. Rev. 6, 3-4 (1947), 202-203.

[22] R. L. Rivest, A. Shamir, and L. Adleman. 1978. A method for obtaining digital signatures and public-key cryptosystems. Commun. ACM 21, 2 (February 1978), 120-126. DOI:https://doi.org/10.1145/359340.359342

[23] Zahr K. Said. 2015. Copyright's Illogical Exclusion of Conceptual Art. Colum JL Arts 39, (2015), 335.

[24] Rod Stewart. 2012. Rod: the autobiography (First edition ed.). Crown Archetype, New York.

[25] United States (Ed.). 1981. Impacts of applied genetics: micro-organisms, plants, and animals. Congress of the U.S., Office of Technology Assessment: For sale by the Supt. of Docs., U.S.G.P.O, Washington, D.C.

[26] Giorgio Vasari. 1748. Delle vite de più eccellenti pittori, scultori et architetti. per gli eredi del Dozza.

[27] José Vitor de Medeiros Viana and Natália Cristina Bleichvel. 2019. CONDIÇÕES FUNCIONAIS E ESTRUTURAIS DE UMA OBRA DE ARTE ESPECIAL E O LEVANTAMENTO DAS CARACTERÍSTICAS PARA FICHA DE INSPEÇÃO CADASTRAL DE ACORDO COM A NBR 9452. Ignis Periód. Científico Arquitetura E Urban. Eng. E Tecnol. Informação (2019), 32-43.

[28] 2009. Against perpetual copyright - Lessig Wiki. Retrieved April 30, 2021 from https://web.archive.org/web/20091103224919/http://wik i.lessig.org/index.php/Against_perpetual_copyright

[29] 2015. How Copyright Law Changed Hip Hop: An Interview with Public Enemy's Chuck D and Hank Shocklee - Little Village. Retrieved May 3, 2021 from https://web.archive.org/web/20151025215554/https://lit tlevillagemag.com/how-copyright-law-changed-hip-hop -an-interview-with-public-enemys-chuck-d-and-hank-sh ocklee/

[30] 2021. Biography of Sol LeWitt, Conceptual Artist. Retrieved May 2, 2021 from https://web.archive.org/web/20210420132946/https://w ww.thoughtco.com/sol-lewitt-biography-4582474

[31] art, n.1. OED Online. Retrieved April 27, 2021 from http://www.oed.com/view/Entry/11125

[32] EUR-Lex - 31998L0071 - EN - EUR-Lex. Retrieved April 30, 2021 from https://eur-lex.europa.eu/legal-content/EN/ALL/?uri=CE LEX:31998L0071 
April 2021, Helsinki, Finland

[33] Groklaw - An Explanation of Computation Theory for Lawyers. Retrieved April 30, 2021 from

https://web.archive.org/web/20210419030813/http://ww w.groklaw.net/article.php?story=20091111151305785

[34] Procedure File: 2002/0047(COD) | Legislative Observatory | European Parliament. Retrieved April 30, 2021 from

https://oeil.secure.europarl.europa.eu/oeil/popups/fiche procedure.do?lang $=$ en\&reference $=2002 / 0047$ (COD)

[35] Conceptual Art Wasn't Meant to Be Collected. Now It Sells for Six Figures. Retrieved from

https://web.archive.org/web/20210125024453/https://w ww.artsy.net/article/artsy-editorial-conceptual-art-meant -collected-sells-six-figures 